\title{
Measuring the Value of Strategic Alliances in the Wake of a Financial Implosion: Evidence from Japan's Financial Services Sector
}

\author{
Ingyu Chiou \\ School of Business \\ Eastern Illinois University \\ 600 Lincoln Avenue \\ Charleston, IL 61920-3099 \\ (217)581-6036 \\ e-mail: ichiou@eiu.edu \\ Lawrence J. White \\ Leonard Stern School of Business \\ New York University \\ 44 West 4th Street \\ New York, NY 10012-1126 \\ (212)998-0880 \\ e-mail: lwhite@stern.nyu.edu
}

Draft: 10/8/03

Please do not quote or cite without the permission of the authors

We would like to thank Benedicte Reyes, Raj Varma, Yasu Hoshino, and participants in the 2000 Southern Finance Association, 2001 Financial Management Association, and 2002 APFA/PACAP/FMA meetings for helpful comments. Ingyu Chiou gratefully acknowledges a 2001 Summer Research Grant (No. 1-00204) from Eastern Illinois University. We also thank Minyuan Zhoa, Anjela Kniazeva, and Diana Kniazeva for their research assistance. 


\begin{abstract}
$\underline{\text { Abstract }}$
This paper examines the wealth effects of financial-institution strategic alliances on the shareholders of the newly allied firms. Our paper is different from previous studies of non-financial joint ventures, financial and non-financial mergers and acquisitions, and non-financial strategic alliances in three important aspects/ways: First, we focus on financial institutions that form strategic alliances. Second, while most related studies use U.S. data, this paper employs Japanese data for the late 1990s, directly testing financial theory in a different setting. Finally, we study whether different types of alliances result in differing magnitudes of stock market responses.

Our primary results are as follows: First, we find that a strategic alliance, on average, increases the value of the partner firms. This is consistent with the "synergy" hypothesis. Second, the gains from the alliance are spread more widely among the partners than would be suggested by a random alternative, supporting a "win-win" hypothesis. Third, smaller partners tend to experience larger percentage gains, which is consistent with a "relative size" hypothesis. Fourth, the market values inter-group alliance announcements more than intra-group alliance announcements; the latter may well be seen as redundant. This is consistent with an "inter-group synergies" hypothesis. Fifth, we do not find a significant difference in the abnormal returns showed by domestic-foreign alliances and domestic-domestic alliances, although both sets of alliances show significantly positive returns. We thus do not find support for a "foreign firm superior" hypothesis. Finally, we find that an investment-banking alliance has a strong positive effect on abnormal returns, indicating that investment banking, which has been underdeveloped in Japan relative to the U.S., may be a promising business for financial institutions.

Overall, this paper complements the existing literature in that we analyze the value of financial institution alliances. Our analysis reconfirms that strategic alliances are value-enhancing. This is consistent with previous studies that find increased value in the announcement of a strategic alliance or a merger. Our results are consistent with the notion that financial deregulation tends to increase competition, which, in turn, encourages firms to adopt aggressive corporate strategies. This is viewed as a positive move by investors, as evidenced by the average gains of the shareholders of these alliance-forging firms.
\end{abstract}




\section{Introduction}

In a modern economy, corporations (both financial and non-financial) often pursue a variety of strategies to achieve different stated objectives. Whether it is financerelated, marketing-related, or operation-related, a sensible strategy should be expected to strengthen a firm's competitive advantages and therefore increase firm value in the long run.

Among various types of corporate strategies, strategic alliances are commonly used by many non-financial firms. ${ }^{1}$ Broadly defined, a strategic alliance can take many different forms, including non-contractual agreements, contractual agreements, joint ventures, and (at the limit) mergers and acquisitions. Unlike many single-firm strategies (e.g., stock repurchases), strategic alliances are special, in that an alliance usually involves two or more firms and these partner firms form an alliance so as to be able to continue to focus resources on their own core skills and competencies while being able to utilize other components or capabilities from the partner firms.

One natural question arises: Are strategic alliances value-enhancing? In response to this question, a number of empirical studies have documented the effects of joint ventures between non-financial firms on the shareholder wealth of partner firms. Also, a few empirical studies have examined the effects of bank mergers and acquisitions (an extreme form of strategic alliance) on the stock prices of acquiring and target banks. In addition, numerous papers in corporate finance have investigated the abnormal stock returns of non-financial firms upon the announcement of a merger or acquisition.

\footnotetext{
1 According to CIO Magazine (October 15, 1999), more than 20,000 corporate alliances were formed worldwide during 1997-1998.
} 
What goes unanswered is: What effect does a strategic alliance involving financial institutions have on the stock prices of the partner institutions? This paper attempts to answer this question by examining the wealth effects of financial-institution strategic alliances on the shareholders of the newly allied firms. To the best of our knowledge our paper is the first one to measure empirically the value of strategic alliances among financial services firms.

Our study is related to three main lines of research. The first line of research investigates the wealth effects of mergers and/or acquisitions generally. The broad evidence, recently summarized by Andrade, Mitchell, and Stafford (2001), that the shareholders of acquired firms earn positive and statistically significant abnormal returns, while the abnormal returns of acquiring companies are generally negative but not significantly different from zero. ${ }^{2}$ The net combined effect is positive and significant.

The second line of research looks into the benefits of non-financial joint ventures. Using a sample of joint ventures involving only U.S. firms, McConnell and Nantell (1985) find that significant wealth gains are created from joint ventures and that the smaller partner in a joint venture usually earns a larger positive abnormal return. Crutchley, Guo, and Hansen (1991) study cross-border joint ventures formed between Japanese and U.S. firms. They find that both Japanese and U.S. shareholders benefit from the announcement of an international joint venture. Specifically, one interesting result is that larger Japanese firms, relative to their U.S. partners, earn larger abnormal returns, whereas smaller U.S. firms, relative to their Japanese partners, gain more. Chan, Kensinger, Keown, and Martin (1997) use 345 non-equity strategic alliances between U.S. firms over the period 1983-1992 to examine the wealth effects of alliance announcements. They document that positive

\footnotetext{
${ }^{2}$ See also earlier surveys by Jensen and Ruback (1983) and Jarrell, Brickley, and Netter (1988).
} 
abnormal returns are associated with strategic alliances, and there is no evidence of wealth transfers between partners. They also find that compared with marketing alliances, horizontal alliances create more value when they involve the transfer and/or pooling of technical knowledge.

The third line of research analyzes the wealth effects of U.S. bank mergers and acquisitions. Desai and Stover (1985) examine the wealth effects of a bank holding company's shareholders when the bank holding company initiates an intra-state acquisition. They find that significant positive abnormal returns to bank holding company shareholders are associated with the announcement of an acquisition. This result, they argue, is consistent with the shareholder value-maximizing behavior of the bank holding company management. James and Wier (1983) examine 60 intra-state bank acquisitions over the period 1972-1982 to determine the sources of acquirer gains. They find that gains to acquirers are positively related to the number of alternative targets and negatively related to the number of potential bidders. Neely (1987) studies 26 successfully acquired and acquiring banking firms over the period 1979-1985. His major finding is that while target bank shareholders earn large abnormal returns during the announcement week, acquirers' returns are slightly negative during the same week. Cornett and De (1991) investigate stock market reactions to the 152 announcements of interstate bank mergers that took place in the U.S. during the period 1982-1985. They document that both the bidding and target banks earn significant positive abnormal returns. With respect to the target banks, the finding is consistent with those of most studies that focus on non-financial mergers and acquisitions. 
Our paper is different from previous studies on non-financial joint ventures, financial and non-financial mergers and acquisitions, and non-financial strategic alliances in three important aspects or ways. First, we focus on financial institutions that form strategic alliances. Second, while most related studies use U.S. data, this paper employs Japanese data for the late 1990s, directly testing financial theory in a different setting. Finally, we examine whether different types of alliances result in differing magnitudes of stock market responses.

This paper is organized as follows: Section II summarizes the Big Bang financial reform in Japan. We discuss theories about strategic alliances and propose some hypotheses in Section III. Section IV describes data, summary statistics and methodology, and presents our results. Section V discusses some implications of our findings. Section VI summarizes and concludes.

\section{The Big Bang Financial Reforms}

In order to understand the context for our study of strategic alliances among Japanese financial firms in the late 1990s, some background on the Japanese financial system and the policy changes of the 1990s may be useful. ${ }^{3}$

On November 11, 1996, Japan’s Prime Minister Ryutaro Hashimoto announced a plan to open up, reform, and substantially deregulate the country's financial sector. This “Big Bang” reform plan aimed at reviving Japan’s financial markets by making them free (in competition), fair (on rules), and global (in terms of participants) by 2001. The ultimate goal was to make the Tokyo financial markets among the largest international financial centers, comparable with those of London and New York. The proposed deregulation measures were designed to allow the establishment of financial holding

\footnotetext{
${ }^{3}$ Additional background can be found in, for example, Sheard (1989, 1994), Aoki, Patrick, and Sheard (1994), Craig (1998), and Chiou (2001).
} 
companies, to enhance asset securitization, to improve electronic settlements, to expand the permissible activities of banks and securities companies, to liberalize foreign exchange services, and to revitalize securities markets.

Similar to the pre-1999 financial system in the U.S., ${ }^{4}$ commercial banking, investment banking, and insurance businesses in Japan had been separated strictly until the early 1990s. ${ }^{5}$ In addition, the banking industry has been quite segmented in that the industry is further divided into three categories: commercial banking, long-term banking, and trust banking, with different laws governing different types of banking business. While the Big Bang plan represented the first comprehensive structural reform in Japan's financial system, financial deregulation has been occurring since the early 1990s, though, at different paces and degrees.

Since the November 1996 announcement, a few major pieces of legislation have been passed and implemented. The major legislative changes can be categorized into the following major areas. ${ }^{6}$

\section{A. Institutional-Structure Reform}

Holding companies ${ }^{7}$ were banned by Section 9 of the Anti-Monopoly Act of 1947 during the post-World War II U.S. occupation of Japan in an effort to prevent the reemergence of pre-war zaibatsu conglomerates because they helped finance much of

\footnotetext{
${ }^{4}$ The U.S. Congress passed the Gramm-Leach-Bliley Act (Financial Modernization Act) in November 1999 to allow mutual entry between commercial banks, insurance companies, and securities firms.

${ }^{5}$ Article 65 of the Securities Exchange Act (the equivalent of the Glass-Steagall Act of 1933 in the U.S.) mandates a clear separation between commercial banks and securities firms in Japan.

${ }^{6}$ In addition to the direct effects on the Japanese financial sector described in the text below, the reforms also affected the structure and responsibilities of the Bank of Japan and the Ministry of Finance.

${ }^{7}$ A holding company's principal business is to control the business activities of a company or companies by holding a controlling stake.
} 
Japan's war efforts. Since its inception, the Act had been amended a few times to adapt to the changing corporate environment.

In March 1998, an amendment to the Banking Law, together with an amendment to the Anti-monopoly Act, lifted the ban on financial holding companies that control other financial institutions through the equity shares of these institutions. The structure of holding companies not only allows mutual entry between banks and securities firms but also provides closely related financial institutions of different industries with more flexibility in realigning similar lines of business, thereby creating synergies and increasing group-wide efficiency. By now, a financial holding company can control asset management companies, banks, investment trust companies, securities firms, and trust banks.

\section{B. Foreign Exchange Reform}

Foreign exchange transactions in Japan had been strictly regulated by the Foreign Exchange and Foreign Trade Control Law dating back to 1949, when Japan's economy recovered slowly from World War II and the government attempted to keep capital from fleeing the country. Until the mid-1990s, only government-authorized banks were permitted to conduct currency transactions for companies and individuals, including trading companies and securities firms that have frequent needs for currency transactions.

Starting in April 1998, the amendments to the 1949 Law have eliminated the licensing and prior notification requirements for cross-border capital transactions and foreign settlements between debts and claims with overseas customers. Also, authorized foreign exchange banks lost their half-century monopoly on changing currencies. In 
addition, companies and individuals can freely open bank accounts abroad, from which they can settle trades in less restricted foreign markets, make direct settlements in foreign currencies, and buy foreign securities from overseas brokerage houses. The revised law basically lets every Japanese individual and company deal with foreign exchange freely. These changes represent a fundamental reconsideration of Japan's foreign exchange controls and are viewed as a precursor to the Big Bang plan.

\section{Securities-Related Reform}

To allow securities firms' entry into the banking industry, since October 1997 securities firms have been allowed to offer so-called universal (or wrap) accounts where customers can deposit paychecks and pay bills and whose returns are tied to the performance of stocks, bonds, and other investments. Also, over-the-counter sales of derivative products have been permitted. To enhance the competition in the brokerage industry, commissions on stock trades of more than 50 million yen were deregulated in April 1998. In October 1999, fixed commissions on stock trades of any size were completely abolished. ${ }^{8}$ With market-determined stock-trade commissions and the emergence of on-line trading, investors have reaped the benefits of stock trading.

\section{Fund Management Reform}

\footnotetext{
${ }^{8}$ The U.S. experienced its “Big Bang” on May 1, 1975 ("May Day”), when fixed stock-trade commissions were abolished. In October 1986, the UK scrapped fixed commissions on share transactions.
} 
Starting in October 1998, investment advisors have been allowed access to corporate pension funds, ${ }^{9}$ paving a way for the creation of U.S. 401k-style pension plans that provide a set of investment choices to pension participants.

Since December 1998, the amendments to the Securities and Exchange Law, the Banking Law, and other related laws have added more freedom for banks, securities companies, and foreign participants. In particular, regulatory changes have significantly opened Japan's investment trust (mutual fund) industry to foreigners. Traditionally, investment trusts and offshore funds were distributed solely through brokers. For onshore funds, the new rules expand distribution channels and permit the delegation of investment management authority to foreigners. For example, banks and other financial institutions are allowed to sell shares of domestic investment trust companies and offshore funds at their branches. Also, incorporated investment trusts (closed-end mutual funds), in addition to contractual-type funds, are permitted. Finally, the registration system replaced the licensing system for establishing investment trust and securities companies, significantly reducing the amount of regulatory discretion and delay involved.

As for reforms related to pension plans, the main driving force is that most corporate and public pension plans have been underfunded. There is an urgent need to increase the returns of all pension plans in order to support Japan's workforce, which is aging faster than any other in the world. As a result, restrictions on pension markets have been eased gradually. In 1995, foreign pension advisors gained limited access to a $\$ 200$ billion pool of public pension money administered by the Japanese government. In March 1997, foreign pension advisors were allowed greater access to a $\$ 170$ billion pool

\footnotetext{
${ }^{9}$ According to the Nihon Keizai Shimbun business newspaper, Japan's corporate pension funds totaled about \$680 billion (68 trillion yen) as of March 1998.
} 
of corporate pension assets. Since October 2001, defined contribution pension plans, similar to 401k-type pension plans in the U.S., have been introduced to allow employees to decide on their own how to invest a portion of their pre-tax salaries, typically a fixed amount on a monthly basis.

\section{E. Insurance-Industry Reform}

Deregulation in Japan’s insurance industry started before the November 1996 Big Bang announcement. The revised Insurance Business Law, effective in April 1996, permits mutual entry between life and non-life insurance companies via the establishment of subsidiaries. The revised law also allows insurance brokers to act as intermediaries for more than one insurer in the provision of policy consultation and risk-management services. In addition, the revised law introduces solvency margin standards for monitoring capital adequacy, a policyholder protection scheme, and partial liberalization of premium rates.

In January 1997, the subsidiaries of life insurance companies were allowed partial entry into non-life insurance’s “third sector."10 Starting in September 1997, the premium rates of automobile insurance have been liberalized to reflect the differences in the age, gender, residence, and driving history of policyholders. This is an important step to increase competition in the insurance industry because auto-insurance premiums account for 40\%-60\% of non-life insurers' revenues. In July 1998, non-life insurers were allowed to set freely the premium rates of more policies. In December 1998, the Life Insurance

\footnotetext{
${ }^{10}$ The third sector refers to the areas not covered by traditional life and non-life insurers, including coverage for cancer, general health, injuries, hospitalization, elderly care, and so on. Non-Japanese insurance companies have dominated in this sector.
} 
Association of Japan adopted a guarantee system that will honor policies if the issuing life insurance company of these policies fails.

\section{F. Financial Reporting Reform}

In April 1999, new accounting rules were adopted to increase financial disclosure about investment losses and risky debt in firms' affiliates and subsidiaries. The new rules require a parent company to report consolidated financial results of all the companies controlled by the parent company, in addition to the unconsolidated financial results of the parent company itself. The design of these new rules is aimed to reduce the probability of loss transfer between an affiliate (or subsidiary) and the parent company and to allow investors more accurately to evaluate Japanese firms.

Starting from April 2000, all companies are required to report the market values of their holdings of bonds and stocks, except for long-term equities. Also, companies are required fully to disclose pension-fund assets and liabilities. Starting in April 2001, market value accounting has been applied to the current assets of all companies. Some $60 \%$ of any paper losses have to be booked as a reduction in retained earnings.

According to Pacific Data Co., a consulting company that tracks earnings in Japan, the accounting changes have started clarifying earnings statements of many Japanese companies. For instance, Toyota Motor Corp. has begun detailing lease transactions. NEC Corp. revised its way of calculating cash flows so that how money flows in from operations is shown more clearly. 


\section{G. Other Competition-Enhancing Reforms}

To tear down the walls between banks and securities firms, in December 1997 banks (and insurance companies) were allowed to rent space in their branches to mutual fund companies to sell mutual funds. Prior to December 1997, securities firms were the only channel for sales of mutual funds. Starting in December 1998, banks have been allowed to sell mutual funds developed by themselves. In October 1997, the brokerage subsidiaries of banks were permitted to trade convertible bonds, warrants, warrant bonds, stock options, and stock index futures.

In sum, a large number of changes in financial regulations have been implemented before and after the November 1996 Big Bang announcement. To cope with increased competition, many Japanese financial institutions have repositioned themselves and adopted different strategies in response to a new financial environment. One major consequence is that there has been a flurry of strategic alliances announced in the past few years. Some alliance examples are explained in Appendix B.

\section{Theories; the Nature of Alliances; and Testable Hypotheses}

Miles and Snow (1986) point out that network organizations are an alternative to the traditional integrated corporation. Jensen and Meckling (1991) describe a strategic alliance as a network organization under which the coordinating functions of integrated firms are combined. Hence, strategic alliances are inter-corporate, cooperative agreements that lie in a continuum, with informal cooperative agreements at one end of the spectrum, and mergers and acquisitions at the other end of the spectrum, and many different forms between the two extremes. A good example of an informal cooperative 
agreement could be an implicit, non-contractual agreement between a bank and an insurance company that they will refer customers to each other.

The resource-based view of the firm suggests that capabilities and resources may be heterogeneously distributed across firms. It is commonly observed that some capabilities and resources are usually scarce, imperfectly imitable, and with no direct substitutes (Barney, 1991). In addition, since some resources are either mingled with other resources or embedded in organizations, they are not separable and may not be transferred perfectly. As a result, the trading and accumulating of resources becomes compulsory, leading to the employment of strategic alliances (Das and Teng, 2000).

From the perspective of resources, alliances allow a firm access to appropriate resources of other firms so that the firm can gain competitive advantages. In terms of the degree of resources committed, informal cooperative agreements can be thought of as the weakest form of alliance because few resources are committed while mergers and acquisitions are the strongest form of alliance because a merger combines all the resources of two companies under one management to achieve some objectives.

Specifically, we define an alliance as a cooperative, voluntary agreement between partner firms involved in the co-development of products, technologies, or services; the entrusting of monetary assets; the exchange or sharing of know-how; the joint-marketing of products or services; the licensing of products, technologies, or services; the tie-up of equity capital; and/or joint ventures. In the context of this paper, alliances could encompass informal cooperative agreements but also extend to cross shareholdings, joint ventures, or even comprehensive tie-ups, but exclude mergers and acquisitions; that is, 
we focus on non-merger and non-acquisition corporate partnerships. Our sample consists solely of financial institutions: banks, insurance companies, and securities firms.

\section{A. Benefits, Costs, and Characteristics of Alliances}

Several previous studies have addressed the benefits and costs of strategic alliances. ${ }^{11}$ First, alliances may lead to knowledge alignment between partner firms. Jensen and Meckling (1991) argue that strategic alliances are more cost-effective than integrated corporations because they can add more value to the partner firms by better aligning decision-making authority with decision knowledge. Jensen and Meckling, however, note that the knowledge transfer of some specific information may be costly. Chesbrough and Teece (1996) point out that general or codified information such as nontechnical data can be transmitted easily and inexpensively, whereas tacit information may be difficult to transfer between firms. An example in the financial services industry would be the deal-making (e.g., mergers and acquisitions) know-how of an investment banker or a group of investment bankers whose knowledge cannot be acquired easily by others in a short period of time. Another cost in transferring information between firms is the possibility that rival firms may acquire competitively sensitive information from any of allied firms.

Second, alliances provide organizational flexibilities. A merger combines two independent companies into a single one by joining together all the resources of two companies. Once the new company is formed, it would be costly to do a de-merger if

\footnotetext{
${ }^{11}$ In addition to the studies mentioned in the text, further discussion and evidence can be found in Berg and Friedman (1978, 1981), Duncan (1982), Harrigan (1985), Kogut (1988), Barney (1991), Lorange and Roos (1992), Bleeke and Ernst (1995), Yoshino and Rangan (1995), Kranton (1996), Mohanram and Nanda (1996), Gulati (1998), and Elmuti and Kathawala (2001).
} 
things go wrong. In contrast, strategic alliances provide organizational flexibilities in that firms with similar interests can form links easily relative to mergers/acquisitions, which often require lengthy pre-merger negotiations and costly post-merger execution. ${ }^{12}$

Also, when market conditions become unfavorable, an alliance can be disbanded quickly. Jensen (1993) argues that network organizations or alliances are a natural strategic response to the difficulties encountered in fully integrating resources from firms. Mody (1993) suggests that with the organizational flexibility, strategic alliances facilitate experimentation with new combinations of partner firms in the pursuit of marketing strategies or new technologies. We argue that a company may form an alliance in order to establish more future alliances with the same or different companies. In other words, alliances are relationship-building and -investing strategies that increase the mutual understanding of partner firms and hence reduce transaction costs. It is also possible that an alliance between two partner firms may be the catalyst for a higher-degree of alliance such as a merger or acquisition. In this sense, an alliance may be considered as the "dating” stage, which may lead to the "marriage" status (i.e., merger or acquisition) in the future. In our sample, the initial trust-business alliance between Dai-Ichi Kangyo Bank, Fuji Bank, and Yasuda Trust \& Banking eventually resulted in a joint holding company.

Third, alliances can circumvent antitrust regulations. A merger or acquisition between two financial institutions is usually subject to regulatory approval because the financial services industry is heavily regulated in virtually all countries. Such a merger or acquisition can also raise anticompetitive concerns. In contrast, a strategic alliance can mitigate these regulatory and public-concern issues, thereby reducing the cost associated

\footnotetext{
${ }^{12}$ However in the presence of open exit opportunities and strong competition, enforceability of such strategic alliances is a key issue in determining the efficiency of the alliance.
} 
with regulatory uncertainty. In fact, unlike the U.S. where financial-institution mergers are frequent, ${ }^{13}$ mergers in Japan's financial services sector have been rare until recently, in part because of regulatory hurdles.

Fourth, we argue that alliances may be a defensive or even survival strategy. Deregulation tends to induce more competition and usually consolidation as well. When some companies in one industry have formed alliances to gain competitive advantages in the wake of deregulation, this puts pressures on other companies that do not have alliance partners. As a consequence, more companies in the industry will enter alliances of different types in order to survive and better compete. If a company acts too late, the choice of suitable partners may be limited, resulting in some disadvantages for the company. This could explain what has happened in Japan’s financial services sector after the November 1996 announcement of the Big Bang financial reforms. Therefore, when the regulatory environment changes, alliances may become an urgently needed strategy. In this sense, alliances could be "contagious."

Fifth, alliances usually incur some costs that are not incurred in the integrated firm. These costs arise mainly from the potential opportunistic behavior by the allianceforging firms. To deter opportunistic behavior, partner firms need to spend extra time and money looking for reliable partners, designing appropriate contracts, and monitoring the behavior of each other. Parkhe (1993) argues that when a current alliance may lead to more cooperative agreements between partner firms in the future, opportunistic behavior may be contained. However, the opportunistic behavior between established partner firms may not be a serious problem if this behavior is verifiable. The reason is that by

\footnotetext{
${ }^{13}$ It should be noted that the U.S. has had a large number of banking mergers because of the existence of a large number of banks and easy entry; despite over 10,000 bank mergers between 1980 and 1998, there were 8,774 banks in the U.S. at year-end 1998. By contrast, Japan had only about 200 banks as of 1998.
} 
behaving opportunistically, a partner firm may suffer a reputational loss because it will reduce the trustworthiness of the firm. This, in turn, may hurt the future profits of the firm. ${ }^{14}$

\section{B. The Nature of Financial Services, and Alliance Examples}

One major difference between a product market and a financial market is that the prices of most financial products or securities are market-determined and these prices keep changing. Therefore, risk is one of important elements in financial services. The nature of financial services has led financial institutions to collaborate in a large number of business areas, even though the same financial institutions may also compete fiercely with each other. In fact, financial institutions are often simultaneously rivals, partners, and customers to each other. By closely examining the activity of financial institutions, we find that strategic alliances among financial institutions are, in fact, abundant. We classify some common alliances into two categories: "transaction-based" and "unavoidable". We also discuss some special types of alliances observed between Japanese financial institutions.

\section{B.1. Transaction-Based Alliances}

One popular form of alliance in the securities industry is syndicated underwriting. Investment banks play an important role in the capital-raising process by offering advice on the type of securities to be sold, the size of the issue, the features of the securities, the distribution channel of the issue, the price, the timing of the sale, and so on. To resell new

\footnotetext{
${ }^{14}$ However, the more costly is the verification or the enforcement of an agreement contingent on verification, the weaker will be the enforcement effects of reputation.
} 
securities quickly for a profit and reduce the underwriting risk, the lead underwriter normally invites other investment banks to form a syndicate, or group of investment banks. Moreover, the underwriting syndicate often expands the syndicated alliance by including other securities companies to form a selling group that distributes newly issued securities to investors. Although a syndicated alliance is normally transaction-based, the large number of securities offerings has made syndicated underwriting a form of repeated alliances between many securities companies.

Another frequently observed alliance is loan syndication, which is normally arranged by a group of major commercial banks (and investment banks) and is particularly popular in international lending. ${ }^{15}$ Typically, a small group of informed and well-capitalized banks agree to provide a relatively large loan to a government or large corporation. These banks, called lead banks, may then sell portions of the entire loan to a wide range of smaller banks (and other financial institutions).

\section{B.2. Unavoidable Alliances}

The nature of financial transactions also has led financial institutions to cooperate in areas such as money transfer, payment system, securities clearing and settlement, and so on. The cooperation is, indeed, "unavoidable” because any financial institution is normally involved in numerous daily transactions with many other financial institutions. The payment system is a good example.

Japan's payment system has been established to meet the preference of the majority of Japanese who favor cash transactions. At the center of the payment system

\footnotetext{
${ }^{15}$ Major investment banks such as Goldman Sachs are also important players in the syndicated-loan market. For simplicity, we focus on commercial banks only.
} 
are Japanese banks. The network systems of participating banks are inter-connected through a shared industry network for each financial industry sector. Among three industry networks, the Bank of Japan Financial Network System (BOJ-NET) is for largevalue funds, the Zengin system for retail payments, and the MICS for ATM networks. The purpose of the payment-system alliance between participating banks is to reduce operating costs, provide real-time online processing services, and reduce the overall settlement risk. $^{16}$

Securities companies also have to cooperate in some areas such as securities clearing and settlement in order to make financial transactions smooth. The clearing and settlement procedure for securities trades involves trade comparison, trade netting, bookentry settlement, and money transfer. Without a centralized clearing organization, trade clearing and settlement would not be efficient. To facilitate the clearance and settlement of securities trades, financial institutions often establish jointly a clearing house. In Japan, the Japan Securities Clearing Corporation (JSCC, a subsidiary of the Tokyo Stock Exchange (TSE)) is in charge of the book-entry settlement for all stocks listed on the TSE while the money settlement is completed through the Bank of Japan and TSE-designated settling banks. The JSCC is just an alliance between major securities companies. ${ }^{17}$

In sum, we observe that the nature of financial services or transactions leads financial institutions to form alliances of various types. The cooperative and coordinated

\footnotetext{
${ }^{16}$ There are similar payment systems in the U.S. Large-amount fund transfers are accomplished through the Federal Reserve's FedWire system and through the Clearing House Interbank Payments System (CHIPS), which was originally organized by major U.S. banks to process international payments. An example of international cooperation is in fund transfers between international banks and other institutions, which are accomplished through an electronic message transmittal system, called the Society for Worldwide Interbank Financial Telecommunications (SWIFT, headquartered in Brussels, Belgium).

${ }^{17}$ Similarly, in the U.S., the trading of corporate bonds, equities, and municipal debt is ultimately processed by the Depository Trust \& Clearing Corporation (DTCC), which is an alliance between member financial institutions (see http://www.dtcc.com).
} 
activities between financial institutions in payment systems, securities clearing and settlement, and other areas can be thought of as unavoidable and silent alliances, because financial institutions need to participate in an efficient money-transfer or post-trading system in order to handle numerous transactions and because these alliances have gone little noticed and moved on quietly for a long period of time.

\section{B.3. Existing Japanese-Style Alliances ${ }^{18}$}

Corporate Japan has long been known for its bank-dominated corporate financing and governance system, in which firms borrow most funds from banks and banks play an active and unique role in corporate governance. Among many distinguished features, the main bank system and corporate grouping are the most noticeable.

Aoki, Patrick, and Sheard (1994) define the main bank system in Japan as "a system of corporate financing and governance involving an informal set of practices, institutional arrangements, and behaviors among industrial and commercial firms, banks of various types, other financial institutions, and the regulatory authorities.” They characterize the main bank system as a nexus of relationships, consisting of three major elements: (1) financial, informational, and managerial relationships between a typical Japanese firm and its main bank; (2) non-contractual, reciprocal relationships among major banks and other financial institutions; (3) cozy and conflicting relationships between the banking industry and regulatory authorities, namely, the Bank of Japan and the Ministry of Finance. In Japan, the main bank of a firm (or group of firms) normally provides the largest share of funds to the firm, holds equity in the firm, and performs the

\footnotetext{
${ }^{18}$ Some specific examples of some of the types of alliances discussed in the text can be found in the Appendix.
} 
functions of monitoring and governance. In the eyes of financial-market participants and regulators, which bank is the main bank to which firm is generally clear and recognized.

Another institutional feature of the Japanese financial system is the formation of keiretsu, or corporate groupings. In a typical financial or horizontal keiretsu (bankcentered corporate group), there are usually a major city bank (as the main bank to other group members), some financial institutions (insurance companies, securities companies and/or trust banks), a trading company, and firms from diverse industries. All groupaffiliated firms are connected by interlocking shareholdings, main bank relationships with the same bank, varying degrees of reciprocal business transactions, and memberships in a presidents' club.

The characterization of the main bank system by Aoki, Patrick, and Sheard (1994) as a nexus of relationships indicates some distinguished institutional features of Japan's financial system. We argue that most observed relationships in the main bank system and corporate groups are, indeed, a bundle or nexus of strategic alliances, which are bilateral or multi-lateral, non-contractual, implicit, multi-dimensional, and long-term in nature. Since our paper is about financial-institution alliances, we will discuss these alliances only.

First, there are alliances in information-sharing. Financial institutions in each of six major bank-centered corporate groups (horizontal keiretsu) constantly exchange information about group-affiliated firms and developments in the business world. These same financial institutions also participate in a monthly meeting, called the presidents' club, in which the executives of all group-affiliated firms may discuss current business issues, share their experiences, and, possibly, jointly agree on something that is in 
everybody's interest. As reported in the financial press, meetings of the presidents' clubs have become less formal in recent years. Even if this is the case, we expect this type of alliance will continue in the future. Also, a main bank may share some information about a client firm with other non-main banks that lend money to the client firm.

Second, there are equity tie-up alliances between financial institutions. In each of six largest financial keiretsu, financial institutions hold each other's shares as well as the shares of group-affiliated firms. According to the Kigyo Keiretsu Soran 1998 (Directory of Corporate Affiliations), there are four financial institutions in the Fuyo financial keiretsu, in which (1) Fuji Bank held a 3.94\% stake of Yasuda Trust \& Banking and a 4.99\% stake of Yasuda Fire \& Marine Co.; (2) Yasuda Trust \& Banking held a 2.18\% stake of Fuji Bank and a 3.88\% stake of Yasuda Fire \& Marine Co.; and (3) Yasuda Fire \& Marine Co. held a 4.89\% stake of Fuji Bank, a 4.05\% stake of Yasuda Trust \& Banking, and a 3.59\% stake of Yasuda Fire \& Marine Co. This type of equity tie-up can be viewed as an intra-keiretsu alliance. Similar shareholding patterns can also be observed five other large financial keiretsu.

In addition, there are inter-keiretsu alliances in that financial institutions of different financial keiretsu normally are joint top shareholders of some large companies and their shareholdings tend to be stable over time. For example, Nippon Steel Corp., one of the largest steel makers in the world, had, as of March 1997, 16 Japanese financial institutions as top 20 shareholders, including 4 financial institutions that belong to the Sakura Bank-centered financial keiretsu. Some other large Japanese companies also have a similar structure of shareholdings. 
Third, there is coordinated lending activity between Japanese financial institutions. Although bank loans in Japan are usually bilateral in that a company borrows directly from a bank, a typical company tends to borrow from a few different banks with the main bank having the largest loan share. It is not uncommon that the main bank will cooperate with other banks to lend to a company.

However, this practice is not in the form of syndicated loans as discussed earlier, but non-contractual coordinated lending. Syndicated loans are still relatively rare for Japanese lenders, ${ }^{19}$ which traditionally extend credit singly to companies with which they have close ties. The volume of syndicated loans in Japan stood at about $\$ 4$ billion in 1998 and grew to about $\$ 37$ billion in 1999. In contrast, the 1999 U.S. volume was about \$1.017 trillion, which is about 27.5 times the comparable volume in Japan.

In the wake of drastic deregulation and economic hard times, Japanese banks have started to move from the main bank system to project financing through a team of banks, where repayments are often based on the returns from the project. Recently, syndicated loans have become more common in Japan as banks want to reduce credit risk as well as to earn arrangement and commitment fees.

Fourth, there are alliances between major banks in monitoring firm borrowers. While a typical Japanese firm borrows from a few different banks, the main bank usually has the largest loan share. Therefore, the main bank traditionally assumes the principal responsibility for monitoring the firm. In practice, because other non-main banks do not monitor the firm with the same intensity, they actually delegate the monitoring task to the

\footnotetext{
${ }^{19}$ For example, Asahi Bank, one of the major city banks in Japan, arranged its first ever syndicated loan of about \$90 million for Sanken Electric Co. in November 2000.
} 
main bank. This relationship is termed "reciprocal delegated monitoring" in Sheard (1994).

\section{Hypotheses}

Overall, alliances are a less costly way for the participating firms to gain partial access to each other's resources and enter new markets while avoiding the expenses incurred when one firm acquires another. Although alliances can result from wideranging motives and objectives, have benefits and costs, and take a variety of forms, it is reasonable to assume that the purpose of an alliance is to enhance competitive advantages of partner firms, and that the ultimate goal of any alliance is to increase shareholder wealth. Based on our previous discussion, we propose the following hypotheses:

First, similar to a typical merger that represents the combination of all the resources of two firms under a single management to accomplish some goals, an alliance is a partnership between participating firms that pool together some subsets of their own resources to reap the benefits of a larger customer base, economies of scale, resource complementarity, increased market power, improved production techniques, improved marketing opportunities, the redeployment of assets to more profitable uses and so on. Therefore, we expect an overall gain from a strategic alliance. As in mergers or acquisitions, we refer to this likely outcome as the synergy hypothesis.

Second, in a typical acquisition or merger, the acquiring firm usually pays a premium to get the approval from the board of the target firm. As a result, the shareholders of the target firm tend to gain substantially, often at the expense of the shareholders of the acquiring firm. Therefore, the hubris hypothesis of corporate 
mergers, proposed by Roll (1986), posits that the gains to target-firm shareholders could be due to wealth transfers from the shareholders of the acquiring firm, not necessarily from synergistic gains. Unlike an acquisition or merger, however, an alliance is a voluntary, cooperative agreement between the partners who foresee benefits of forming such an alliance. If one partner is likely to be negatively affected through an alliance, there seems to be no point for this partner to enter into the alliance because doing nothing is just better (and there are fewer of the managerial advantages, such as greater size of institution and more perquisites, that are a large part of the hubris hypothesis). Therefore, all partners of an alliance should expect to gain. We refer to this expectation as the winwin situation (or non-hubris) hypothesis.

Third, partner firms may benefit differently. According to the relative size hypothesis in McConnell and Nantell (1985), the abnormal return of the smaller partner in a joint venture should be larger than that of the larger partner, but the monetary value of their gains should be approximately equal. Because joint ventures are a subset of strategic alliances in our paper, the relative size hypothesis may hold - at least, in its weaker form (i.e., that the smaller partner's abnormal return should be greater than the larger partner's), if not in its stronger form (i.e., that the monetary value of the gains of the partners should be about the same).

Fourth, in the past twenty years, Japanese banks have played a major role in the international syndicated or bank-loan market. Japanese financial institutions also have been key players in the euro-yen credit market. However, Japanese financial institutions have lagged behind their Western counterparts in areas such as asset management, financial engineering, financial technologies, global merger and acquisition advisory 
services, and international underwritings. For example, for announced global merger and acquisition deals in 1999, Goldman Sachs of the U.S. ranked first, lead-advising 340 deals with a total value of about $\$ 1.12$ trillion (Bloomberg News). By comparison, Nomura Securities of Japan ended in twentieth place (the best among Japanese financial institutions), brokering only eight deals (2.35\% of Goldman's total) valued at about $\$ 45.42$ billion (4\% of Goldman’s). Therefore, for a similar type of alliance, we expect that a domestic/foreign alliance should add more value than would a domestic/domestic alliance, all else being equal. This is referred to as the foreign institution superior hypothesis.

Finally, as we discussed earlier, group-affiliated (keiretsu) firms have had alliances in information-sharing, cross-shareholding, and so on. If a strategy can increase the value of some group-affiliated firms, it may well have been already exploited in some way. Therefore, the announcement of an inter-group alliance should be expected by the market to yield larger returns than should the announcement of an intra-group alliance, all else being equal. We refer to this notion as the inter-group synergy hypothesis.

\section{Data, Methodology, and Results}

\section{A. Sample Description}

We have identified a sample of strategic alliance (te-kei in Japanese) announcements involving Japanese financial institutions over the period 1997-1999 by carefully reading through three major Japanese newspapers: Nihon Keizai Shimbun (Japan Economic Journal), Nikkei Interactive Net, and Yomiuri Shimbun. This search resulted in a total of 258 announcements. Since our focus is on financial institutions, we 
restricted observations to those alliances that involve only banks, insurance companies, and securities firms. Therefore, an alliance between a financial firm and a non-financial firm was excluded. To be included in the sample, we also require that at least one Japanese financial firm involved in each alliance be traded on the Osaka or Tokyo Stock Exchange. Finally, we checked for contaminating news over the (day -3 , day +1 ) window. To avoid concurrent effects of some other firm-specific events, we dropped observations that were related to such news as bond/credit rating changes, corporate control affairs, dividends, earnings, financing arrangements, legal affairs, loan loss reserves, or share repurchases. After applying the above criteria, our primary sample consists of 109 clean announcements, involving 169 publicly traded Japanese financial institutions.

Table 1 presents the sample observations by time of announcement. Most announcements were made in the period of 1998 Q2 to 1999 Q1, with the largest number of announcements in 1998 Q4. In Table 2, we classify each alliance announcement into one of three categories: (1) single-business alliance if only one line of business is involved in the alliance (single-business dummy variable $=1$ ); (2) multiple-business alliance if two or three lines of business are involved in the alliance (multiple-business dummy variable $=1$ ); and (3) comprehensive-business alliance if it involves a wideranging business tie-up or full-scale consolidation in a line of business (comprehensivebusiness dummy variable $=1$ ). For example, a consolidation of securities businesses between two partner firms is considered to be a comprehensive-business alliance. There are 80 single-business alliances (73.39\%), 20 multiple-business alliances (18.45\%), and 9 comprehensive-business alliances (8.26\%), respectively. 


\section{B. Methodology}

Following the conventional event-study methodology, we use the market model to obtain the estimates of abnormal stock returns of the sample firms around the announcements of strategic alliances. ${ }^{20}$ The abnormal return is computed by subtracting the expected (or predicted) return from the realized (or actual) return for each announcement. The estimation period of the market model begins from day -219 and ends on day -20 , totaling 200 trading days. Event day 0 is the day on which the announcement of an alliance was made. For most announcements, we can clearly identify the exact announcement time and date. Hence, our primary focus is on the announcement effect on day 0 . It is, however, possible that there was information leakage before the announcement; we therefore also use a two-day window (day -1, day 0) to measure the impact of the announcement on the stock price of a sample firm. We refer to the two-day window as the (day -1 , day 0 ) announcement period.

In calculating the test statistics employed in most event studies, cross-sectional independence of returns is assumed. If the events are contemporaneous, then the assumption may be violated. Because an alliance in our sample may involve more than one firm, cross-sectional independence of returns may not hold. To correct for this potential problem, we form an equally weighted portfolio using the common stocks of firms in the same alliance. Then, the portfolio is treated as a single "security" in conducting the statistical analysis. Therefore, although 169 firms are represented in our sample, the full sample includes only 109 "securities."

\footnotetext{
${ }^{20}$ See, for example, Brown and Warner (1985) and Barber and Lyon (1996).
} 
To evaluate how other variables affect the abnormal return, we record, if available, the following characteristics associated with each alliance: (1) if it is a domestic firm/foreign firm alliance ( $\mathrm{d} / \mathrm{f}$ dummy variable $=1)$; $(2)$ if it is an alliance between firms within the same business $($ keiretsu) group (intra-group dummy variable $=$ 1); (3) if an alliance is formed between firms from different business (keiretsu) groups (inter-group dummy variable $=1$ ); (4) if an alliance involves an equity tie-up (capital tieup dummy variable $=1$ ); (5) if an alliance involves the insurance business (insurance dummy variable = 1); (6) if an alliance involves investment products (e.g., mutual funds) (investment product dummy variable $=1$ ); (7) if an alliance involves asset management (e.g., pension funds) (asset management dummy variable =1); (8) if an alliance involves the investment banking business (investment banking dummy variable = 1); (9) if the business involved in an alliance cannot be classified as one of (5), (6), (7), or (8) ("others" dummy variable =1). It should be noted that while an alliance cannot be intragroup as well as inter-group, some of these dummy variables are not mutually exclusive. For example, an alliance could involve inter-group firms, asset management, and investment banking.

Table 3 shows the frequencies of the nine dummy variables. The domestic firm/foreign firm alliance, with a frequency of 60 , is the most common characteristic, followed by the equity tie-up with a frequency of 52 and the investment-product alliance with a frequency of 37 . Also, there are 24 alliances in asset management, 20 in other business, 17 between intra-group firms, 9 in insurance business, 7 in investment banking, and 5 between firms from different business groups, respectively. The popularity of the domestic firm/foreign firm alliance may be a manifestation of the foreign-institution- 
superior hypothesis: all else being equal, domestic firms prefer to team up with foreign firms in the hopes of enhancing their competitiveness.

\section{Results}

The hypotheses developed in Section III.C can be summarized as follows:

(1) The "synergy" hypothesis: Strategic alliances should be expected to yield value for their members, which should be reflected in positive abnormal returns at the time of the announcement of the alliance.

(2) The "win-win" hypothesis: All of the partners of an alliance should expect to gain; i.e., all of the partners should expect positive abnormal returns at the time of the announcement.

(3) The "relative size" hypothesis: The smaller members of the alliance will show the larger percentage gains at the time of the announcement.

(4) The "foreign institution superior" hypothesis: A domestic/foreign alliance should add more value than would a domestic/domestic alliance (all else being equal), and thus the abnormal returns for $\mathrm{d} / \mathrm{f}$ alliances should be larger.

(5) The "inter-group synergy" hypothesis: Inter-group alliances should yield more value than intra-group alliances, and thus the former's abnormal returns should be higher.

We will discuss the results and their implications for each hypothesis in turn.

\section{C.1. The "synergy" hypothesis}

Table 4 reports that the (day -1 , day 0 ) average abnormal return is $+2.87 \%$, which 
is significantly different from 0 at the $1 \%$ level. Further, the median value is $+1.39 \%$, which is again significantly different from 0 at the $1 \%$ level. Finally, of the 109 "events" in our sample, 75 (68.8\%) had positive abnormal returns and only 34 (31.2\%) had negative positive returns, which is significantly different from the random (50\%/50\%) outcome at the $1 \%$ level.

All of these outcomes are consistent with the synergy hypothesis that a strategic alliance, similar to a merger or acquisition, generally creates value.

\section{C.2. The "win-win" hypothesis}

To test this hypothesis, we focus on the 37 alliances that involved solely domestic Japanese financial services firms $(\mathrm{d} / \mathrm{f}=0)$ and for which abnormal returns data are available for two or more firms. ${ }^{21}$ Table 5 shows the distribution of domestic-domestic alliances by numbers of participating firms for which abnormal returns data are available, and the signs of their returns. As can be seen, for the 26 domestic-domestic alliances for which there were only two publicly traded firms, 13 (50\%) had positive abnormal returns for both firms. This outcome is significantly different from the randomly expected outcome $(25 \%)$ at the $1 \%$ level. ${ }^{22}$ The outcomes from the three-firm and four-firm distributions are not significantly different from random outcomes. Nevertheless, the two-firm outcomes do point strongly toward the result that alliances tend (more than randomly) to provide benefits for all of their members. ${ }^{23}$

\footnotetext{
${ }^{21}$ There were 49 alliances that involved only domestic Japanese firms, but in 10 of these alliances only one of the alliance partners was a publicly traded firm for which abnormal returns data could be collected.

${ }^{22}$ Also, a chi-square test on the overall frequency of the three outcomes shows that they are significantly different from the randomly expected outcome at the $5 \%$ level.

${ }^{23}$ There appears to be no straightforward way to combine the two-firm, three-firm, and four-firm outcomes to provide an overall test. However, if we simply examine the pattern of abnormal returns for the 93 firms that were involved in these domestic alliances, there were $56(60.2 \%)$ that had positive returns, which is
} 


\section{C.3. The "relative size" hypothesis}

We again will focus on the group of domestic-domestic alliance announcements. In Table 6 we extend the outcomes from Table 5 to ask whether the smaller firm in any given alliance (as measured by the reported assets of the firm, at the time of the announcement) showed larger gains than did the larger firm. For the alliances with two firms' abnormal returns, the smaller firm showed the superior gain in 15 of the 26 announcements. ${ }^{24}$ For the 11 alliances with three firms' abnormal returns, if we examine the returns of the largest and the smallest of the three, the smallest showed better returns in 6 of the announcements. Finally, for the 2 alliances with four firms' abnormal returns, the smallest firm showed better returns than the largest firm in one of the announcements. Overall, more than a majority -- 22 out of the 39 alliances -- showed the smaller firms' having the higher returns; but the results are not significantly different from what we would observe by chance.

However, when we observe the sizes of the differences in abnormal returns between the smaller and larger firms within an alliance, a more systematic pattern emerges. Of the 26 alliances with two firms' abnormal returns, the 15 announcements where the smaller firm had superior returns showed a mean difference between the small and large firms' returns of $+5.23 \%$; the 11 announcements where the larger firm had

significantly different from the 50\% expectation at the $5 \%$ level. This result tends to support the 2-firm result. Also, this result, along with the fact that the overall mean of the domestic alliance abnormal returns (including the alliances for which there is only a single publicly traded firm) was 3.13\% (and significantly different from 0 at the $1 \%$ level), shows that the domestic alliances tracked the overall sample in supporting the "synergy" hypothesis.

${ }^{24}$ These 15 instances were distributed as follows: The smaller firm showed greater abnormal returns in 7 of the 13 announcements where both firms showed positive returns; the smaller firm showed the positive gain in 7 of the 9 announcements where the two firms' abnormal returns were split in sign; and the smaller firm showed a smaller loss in 1 of the 4 announcements where both firms' abnormal returns were negative. 
superior returns showed a mean difference between the large and small firms' returns of only $+2.62 \%$.

Similarly, when we examine the 11 alliances with three firms' abnormal returns, the 6 announcements where the smallest firm's abnormal returns were better than the returns of the largest firm showed a mean difference of $+5.10 \%$ in favor of the smaller firm; the 5 announcements where the largest firm's abnormal returns were better than the returns of the smaller firm showed a mean difference of only $+3.37 \%$ in favor of the larger firm. Finally, for the 2 alliances with four firms' abnormal returns, for one announcement the smaller firm's returns were superior to the larger firm's by $12.70 \%$, while for the other announcement the larger firm's abnormal returns were superior to the smaller firm's by $0.55 \%$.

When we combine all of these results for all 39 domestic-domestic alliances, we find that for the 22 announcements where the smaller firm showed superior abnormal returns, the mean difference was $+5.53 \%$ (with a standard error of 1.51 ); for the 17 announcements where the larger firm showed superior abnormal returns, the mean difference was only $+2.72 \%$ (with a standard error of 0.64 ). The difference between the two means is significant at the $10 \%$ level.

Thus, though the simple count of which announcements yielded superior abnormal returns for the smallest firm in the alliance does not yield a pattern that is significantly different from what would be expected randomly, the sizes of the differences in abnormal returns do show a systematic pattern. For the announcements where the smaller firm shows superior abnormal returns, the size of the average differential in returns significantly exceeds the size of the average differential for the 
announcements where the larger firm shows superior returns. Thus, this measure of the sizes of the differentials does provide support for the "weak" form of the "relative size" hypothesis.

\section{C.4 The “foreign institution superior" hypothesis}

In Table 7 the entire sample is divided into two sub-samples, $\mathrm{d} / \mathrm{f}=1$ and $\mathrm{d} / \mathrm{f}=0$. The (day -1 , day 0 ) average abnormal return of the $d / f=1$ sub-sample is $2.65 \%$, lower than that $(3.13 \%)$ of the $d / f=0$ sub-sample. While both average abnormal returns are significantly different from 0 at the $1 \%$ level, the larger average AR for the domesticdomestic alliance announcements is not consistent with the foreign institution superior hypothesis. ${ }^{25}$ When we compare the (day -1, day 0) median abnormal returns of the two sub-samples, the $d / f=1$ sub-sample has the larger median, which is consistent with our expectation that a domestic-foreign alliance generally generates a higher abnormal return than a domestic-domestic alliance; but the difference in the medians of the two subsamples is not significant.

To examine further the cross-sectional differences in the abnormal returns for alliance announcements to determine whether other influences may be affecting the pattern of returns observed for the domestic-foreign and domestic-domestic alliances, we introduce various alliance characteristics (expressed as dummy variables) as additional explanatory variables in regressions in which the alliance ARs are the dependent

\footnotetext{
${ }^{25}$ One large abnormal return among the domestic alliance announcements, with a return of $37.5 \%$, clearly has an influence on these results. (The next highest abnormal return in the overall sample is $19.1 \%$.) If this announcement is considered an "outlier" and is removed, then the average abnormal return for the remaining $\mathrm{d} / \mathrm{f}=0$ sub-sample is $2.41 \%$, which is lower than the $2.65 \%$ average abnormal return for the $\mathrm{d} / \mathrm{f}=1$ sub-sample; this simple difference in (corrected) means is consistent with our expectations. The difference in these sub-sample means, however, is not statistically significant.
} 
variables. $^{26}$ We run the following three sets of regressions: ${ }^{27}$

(1) Abnormal return $_{\mathrm{i}}=\alpha_{\mathrm{i}}+\beta_{1 \mathrm{i}}(\mathrm{d} / \mathrm{f})+\beta_{2 \mathrm{i}}$ (intra-group) $+\beta_{3 \mathrm{i}}$ (inter-group)

$$
\begin{aligned}
& +\beta_{4 i} \text { (capital tie-up) }+\beta_{5 i} \text { (insurance) } \\
& +\beta_{6 i} \text { (investment product) }+\beta_{7 \mathrm{i}} \text { (asset management) } \\
& +\beta_{8 \mathrm{i}} \text { (investment banking) }+\beta_{9 \mathrm{i}} \text { (others); }
\end{aligned}
$$

(2) Abnormal return $_{\mathrm{i}}=\alpha_{\mathrm{i}}+\beta_{1 \mathrm{i}}(\mathrm{d} / \mathrm{f})+\beta_{2 \mathrm{i}}$ (intra-group) $+\beta_{3 \mathrm{i}}$ (inter-group)

$$
\begin{aligned}
& +\beta_{4 \mathrm{i}} \text { (capital tie-up) }+\beta_{10 \mathrm{i}} \text { (multiple-business) } \\
& +\beta_{11 \mathrm{i}}\left(\text { comprehensive-business); }{ }^{28}\right. \text { and }
\end{aligned}
$$

(3) Abnormal return $_{i}=f($ combined variables from regressions (1) \& (2)),

where $\mathrm{i}$ is the ith observation or announcement (109 alliance announcements in total) and all betas on the right-hand side are the coefficients on the dummy variables as described in Parts A and B of this section.

Table 8 reports the results of these regressions. For all of the regressions, the coefficient on the $d / f$ variable is insignificantly different from zero. Even when other influences are taken into account, the "foreign firm superior" hypothesis is not supported. $^{29}$

\footnotetext{
${ }^{26}$ Because the ARs themselves are estimated values, with standard errors, their use as a dependent variable introduces the possibility of heteroskedasticity into the regression. To correct for this, we use weighted least squares, where the weights for each observation are the inverse of the standard error of each AR, as suggested by Saxonhouse (1976). Another possible method is to standardize just the ARs themselves by their standard errors (i.e., use standardized prediction errors, or "SPEs"). Accordingly, we also conducted regressions using the SPEs as the dependent variable. Those results (unreported) are largely similar to the results reported in Table 8.

${ }^{27}$ In addition to the reported regressions, we also ran regressions (unreported) that included six-month time period dummy variables (second-half of 1997, first-half of 1998, etc.). Though these time-period dummy variables tended to be significant, they did not affect the other results appreciably.

${ }^{28}$ In this regression, the single-business category is the "base case" (since the sum of the single-business, multiple-business, and comprehensive-business categories sum to 1.0).

${ }^{29}$ We are unsure as to why the "foreign firm superior" hypothesis fails to be supported by the data. One possibility is the problem of self-selection bias. To the extent that firms have discretion as to which alliances they will announce to the public (and they care about the market reaction), they will tend to
} 
When we examine the other coefficients, we find that the intra-group alliance has a negative effect on the standardized abnormal return, and the coefficient is statistically significant at the $5 \%$ level in the first two regressions. The insurance and investmentproduct alliance variables also have negative effects on standardized returns, with significance levels of $10 \%$ and $5 \%$, respectively, in the third regression.

By contrast, the investment-banking alliance is associated with a strong positive effect, with a coefficient that is significant at the $5 \%$ level in the first regression. One of the major consequences of the Big Bang reforms has been increased competition so that Japanese companies are more willing to sell or close money-losing operations. According to the Wall Street Journal (April 23, 2001, A17), the value of Japan’s M\&A market compared to the size of its stock market is probably the lowest among developed countries. The value of mergers in 2000 totaled about $4 \%$ of Japan's stock-market capitalization, compared with $16 \%$ in the European Union and $21 \%$ in the U.S. The growth potential of the investment banking business in Japan may contribute to the favorable reactions from the stock market in response to investment-banking alliances.

\section{C.5 The "inter-group synergy" hypothesis}

In the regression results of Table 8, the coefficient on the intra-group variable is always negative and is significantly different from zero in the first two of the regressions, whereas the coefficient on the inter-group variable is always positive (although it is never

announce only those about which they have greater confidence as to the market's favorable reaction. This flexibility in announcement may not apply equally to domestic-foreign alliances and to domestic-domestic alliances. In the former case, the foreign partner's securities laws may mandate disclosure if the alliance is considered to be a "material event" (e.g., as is true for U.S. securities law), thus reducing discretion. If this is true, then the self-selection may apply more strongly to the domestic-domestic alliances, thus biasing their outcomes upward. 
significantly different from zero). Thus, controlling for other influences, the market reacts more favorably (or less unfavorably) to the announcements of inter-group alliances than to the announcements of intra-group alliances.

These results are supported by the simple mean differences in the abnormal returns for the two kinds of alliances. In Table 9 we present the mean abnormal returns for the 17 announcements of intra-group alliances and the 5 announcements of intergroup alliances. As can be seen, the former set of alliances had a mean abnormal return of $+0.58 \%$; the latter set of alliances had a mean abnormal return of $+4.55 \%$.

Thus, as expected, the inter-group alliance announcements yield higher abnormal returns than do the intra-group alliance announcements - because of the market's likely expectations that the latter alliance announcements are (in a sense) redundant.

\section{C.6 A summing up}

In Section III we put forward five hypotheses concerning the likely pattern of abnormal returns that would be found in connection of the announcements of alliances involving Japanese financial services firms: (1) the "synergy" hypothesis; (2) the "winwin" hypothesis; (3) the "relative size" hypothesis; (4) the "foreign institution superior" hypothesis; and (5) the "inter-group synergy" hypothesis. In this section we have tested these hypotheses on a sample of alliance announcements between 1997 and 1999. We find general support for all of them except the "foreign institution superior" hypothesis. Alliances do seem to be favorably received ("synergy"); the gains are spread among the alliance members more widely than a random pattern would suggest ("win-win"); the 
smaller firm in an alliance tends to do better than the larger firm ("relative size"); and inter-group alliance announcements are more favorably received by the market than are intra-group alliance announcements (“inter-group synergy”). Alliances involving foreign firms, however, do not achieve significantly higher abnormal returns than do domesticdomestic alliances. Foreign partners are valued, but not more so than domestic partners.

\section{Implications of Our Findings}

The stagnant Japanese economy since the early 1990s has caused increased difficulty for Japanese financial institutions, especially banks, while drawing a large amount of international attention. Peaking at 38,915.87 points in December 1989, the Nikkei 225 Stock Index hit 15,258.74 points at the end of 1997, a 60.8\% drop from the 1980s high. Similarly, TOPIX, a broader stock index, peaked at 2,884.8 points in December 1989 and fell to 1,175.03 points at the end of 1997, a 59.27\% drop from the 1980s high. Moreover, the index of residential land prices in the six largest cities dropped about 50\% by 1997, compared with the 1990 index. The continued economic problems have significantly decreased the values of collateral, loan portfolios, and securities holdings in Japan's financial institutions. There is little doubt that the 1990s have been the coldest and longest winter for Japanese financial institutions and their corresponding regulators.

Our findings that a strategic alliance between financial institutions increases firm value, however, should be welcome news and have implications in corporate strategy, regulatory policy, and financial system design. Unlike U.S. companies that often take on aggressive value-enhancing strategies such as acquisitions, spin-offs, stock repurchases, 
and so on, Japanese companies have been laggards in pursuing drastic corporate strategies. The Big Bang financial deregulation has significantly changed the competitive possibilities and the strategic thinking of Japanese financial institutions. They formed alliances to reduce over-capacity, broaden customer bases, and enhance competitiveness. And investors reacted positively to these strategic movements. This favorable reception may encourage financial institutions to adopt more aggressive strategies in the future.

\section{Summary and Conclusions}

This paper examines the announcement effects of strategic alliances involving Japanese financial institutions such as banks, insurance companies, and securities firms. Our primary results are as follows:

First, we find that a strategic alliance, on average, increases the value of the

partner firms. This is consistent with the "synergy" hypothesis. Second, the gains from the alliance are spread more widely among the partners than would be suggested by a random alternative, supporting a "win-win" hypothesis. Third, smaller partners tend to experience larger percentage gains, which is consistent with a "relative size” hypothesis. Fourth, the market values inter-group alliance announcements much more than intragroup alliance announcements; the latter may well be seen as redundant. This is consistent with an "inter-group synergies" hypothesis. Fifth, we do not find a significant difference in the abnormal returns showed by domestic-foreign alliances and domesticdomestic alliances, although both sets of alliances show significantly positive returns. We thus do not find support for a "foreign firm superior" hypothesis. Finally, we find that an investment-banking alliance has a strong positive effect on abnormal returns, 
indicating that investment banking, which is underdeveloped in Japan relative to the U.S., may be a promising business for financial institutions.

Overall, this paper complements the existing literature in that we analyze the value of financial-institution alliances. Our analysis reconfirms that strategic alliances are value-enhancing. This is consistent with previous studies that find increased value in the announcement of a strategic alliance, joint venture, or merger. Our results suggest that deregulation tends to increase competition, which, in turn, encourages firms to adopt aggressive corporate strategies such as strategic alliances. This is viewed as a positive move by investors, as is evidenced by the gains of the shareholders of the allianceforging firms.

Appendix: Examples of different types of strategic alliances

\section{Domestic/foreign alliance}

Nikko Securities of Japan and Travelers Group of the U.S. announced that they had agreed to form a comprehensive alliance in the Japanese market. They unveiled plans to set up a joint venture in which nearly all of Nikko's corporate securities business would be merged with the Japanese arm of Travelers Salomon Smith Barney (The Nihon Keizai Shimbun, 06/02/98).

Domestic/foreign alliance

Dai-Ichi Kangyo Bank, Japan's third largest bank, and J.P. Morgan Co., the U.S.'s fourth largest bank, will launch a 3 billion yen investment-trust joint venture to develop and market investment trusts exclusively through the Japanese bank's branches (The Nihon Keizai Shimbun, 10/01/98).

Intra-keiretsu alliance

Four financial companies in the Mitsubishi group (Bank of Tokyo-Mitsubishi, Meiji Life Insurance Co., Mitsubishi Trust \& Banking Co. and Tokio Marine \& Fire Insurance Co.) announced a comprehensive alliance in insurance, investment trusts, securities and pension-fund management (The Nihon Keizai Shimbun, 09/12/98). 
Inter-keiretsu alliance

Asahi Bank and Tokai Bank jointly announced that they have reached basic agreements on a comprehensive alliance to include cross-shareholding, joint development of derivative financial products, and the integration of redundant branches. The partnership could also be extended to form a joint holding company (The Nihon Keizai Shimbun Evening Edition, 09/28/98).

Inter-industry alliance

Industrial Bank of Japan, the seventh largest bank, and Nomura Securities, Japan's largest brokerage house, said they will form two 50\%-50\% joint venture in derivatives products and asset management, respectively (The Nihon Keizai Shimbun Evening Edition, 05/14/98).

\section{References}

Andrade, Gregor, Mark Mitchell, and Erik Stafford, 2001, New evidence and perspectives on mergers, Journal of Economic Perspectives 15, 103-120.

Aoki, Masahiko, Hugh Patrick and Paul Sheard, 1994, The Japanese main bank system: An introductory overview, in Masahiko Aoki and Hugh Patrick, eds., The Japanese Main Bank System. New York: Oxford University Press.

Barber, B. and J. Lyon, 1996, Detecting abnormal operating performance: The empirical power and specification of test-statistics, Journal of Financial Economics 3, 359-400.

Barney, Jay B., 1991, Firm resources and sustained competitive advantages, Journal of Management 17, 99-120.

Berg, S., Friedman, P., 1978, Technological complementarities and industrial patterns of joint venture activity, 1964-1975, Industrial Organization Review 6, 110-116.

Berg, S., Friedman, P., 1981, Impacts of domestic joint ventures on industrial rates of return: a pooled cross-section analysis, 1964-1975, Review of Economics and Statistics 63, 293298.

Bleeke, Joel, and David Ernst, 1995, Is your strategic alliance really a sale? Harvard Business Review 73, January, 97-106.

Brown, Stephen J. and Jerold B. Warner, 1985, Using daily stock returns: The case of event studies, Journal of Financial Economics 14, 3-31. 
Chan, Su Han, John W. Kensinger, Arthur J. Keown, and John D. Martin, 1997, Do strategic alliances create value? Journal of Financial Economics 46, 199-221.

Chesbrough, Henry W., and David J. Teece, 1996, When is virtual virtuous? Organizing for innovation, Harvard Business Review 74, January/February, 65-72.

Chiou, Ingyu, 2001, A note on Japan’s Big Bang financial reforms: Is it a revolution? Manuscript.

Cornett, Marcia Millon, and Sankar De, 1991, Common stock returns in corporate takeover bids: Evidence of interstate bank mergers, Journal of Banking and Finance 15, 273-295.

Craig, Valentine V., 1998, Financial deregulation in Japan, FDIC Banking Review, Volume 11 , No. 3, 1-12.

Crutchley, Claire E., Enyang Guo, and Robert S. Hansen, 1991, Stockholder benefits from Japanese-U.S. joint ventures, Financial Management, Winter, 22-30.

Das, T.K., and Bing-Sheng Teng, 2000, A resource-based theory of strategic alliances, Journal of Management 26, 31-61.

Desai, Anand S, and Roger D. Stover, 1985, Bank holding company acquisitions, stockholder returns, and regulatory uncertainty, Journal of Financial Research 8, No. 2, Summer, 145-156.

Duncan, L., 1982, Impacts of new entry and horizontal joint ventures on industrial rates of return. Review of Economics and Statistics 64, 339-342.

Elmuti, Dean, and Yunus Kathawala, 2001, An overview of strategic alliances, Management Decision 39, 205-217.

Gulati, Ranjay, 1998, Alliances and networks, Strategic Management Journal 19, 1998, 293-317.

Harrigan, K., 1985, Strategies for Joint Ventures. Lexington Books, Lexington MA.

James, Christopher, and Peggy Wier, 1987, Returns to acquirers and competition in the acquisition market: The case of banking, Journal of Political Economy, April, 355-370.

Jarrell, Gregg A., James A. Brickley, and Jeffrey M. Netter, 1988, The market for corporate control: the empirical evidence since 1980, Journal of Economic Perspectives 2, 49-68.

Jensen, Michael, 1993, The modern industrial revolution, exit, and failure of internal control systems, Journal of Finance 48, 831-880. 
Jensen, Michael C. and Richard S. Ruback, 1983, The market for corporate control: the scientific evidence, Journal of Financial Economics 11, 5-50.

Jensen, Michael, and William Meckling, 1991, Specific and general knowledge, and organizational structure, in L. Werin and H. Wijkander (Eds.), Main Currents in Contract Economics. Blackwell Publishers, Oxford.

Kogut, Bruce, 1988, Joint ventures: Theoretical and empirical perspectives, Strategic Management Journal 9, 319-332.

Kranton, B., 1996, The formation of cooperative relationships, The Journal of Law, Economics, and Organization 12, 214-233.

Lorange, P. and J. Roos, 1992, Strategic Alliances: Formation, Implementation and Evolution. Blackwell Publishers, Cambridge, MA.

McConnell, John J., and Timothy J. Nantell, 1985, Common stock returns and corporate combinations: The case of joint ventures, Journal of Finance 40, 519-536.

Miles, R. and C. Snow, 1986, Network organizations: new concepts for new forms, California Management Review (Spring), $62 \mathrm{f}$.

Mody, A., 1993, Learning through alliances, Journal of Economic Behavior and Organization 20, 151-170.

Mohanram, P. and A. Nanda, 1996, When do joint ventures create value? Academy of Management Proceedings, 36-40.

Neely, Walter P., 1987, Banking acquisitions: Acquirer and target shareholder returns. Financial Management, Winter, 66-73.

Parkhe, Arvind, 1993, Strategic alliance structuring: A game theoretic and transaction cost examination of interfirm cooperation, Academy of Management Journal 36, 794-829.

Roll, Richard, 1986, The hubris hypothesis of corporate takeovers, Journal of Business 59, 1986, 197-216.

Saxonhouse, Gary R., 1976, Estimated parameters as dependent variables, American Economic Review 66:1, 178-83.

Sheard, Paul, 1989, The main bank system and corporate monitoring and control in Japan, Journal of Economic Behavior and Organization 11, 399-422.

Sheard, Paul, 1994, Reciprocal delegated monitoring in the Japanese main bank system, Journal of the Japanese and International Economies 18, 1-21. 
Yoshino, M. and U. Rangan, 1995, Strategic Alliances: An Entrepreneurial Approach to Globalization. Harvard Business School. 
Table 1: The Time Distribution of 109 Strategic-Alliance Announcements

\begin{tabular}{lcc}
\hline Time of Announcement & Number of Announcements & Percent of Total \\
1997 Q1 & 1 & $0.92 \%$ \\
1997 Q2 & 1 & 0.92 \\
1997 Q3 & 6 & 5.5 \\
1997 Q4 & 5 & 4.59 \\
1998 Q1 & 6 & 5.5 \\
1998 Q2 & 14 & 12.84 \\
1998 Q3 & 11 & 10.09 \\
1998 Q4 & 20 & 18.35 \\
1999 Q1 & 16 & 14.68 \\
1999 Q2 & 8 & 7.34 \\
1999 Q3 & 11 & 10.09 \\
1999 Q4 & 10 & 9.17 \\
Total & & \\
& 109 & $100 \%$
\end{tabular}


Table 2: The Sample Distribution of 109 Strategic-Alliance Announcements by the Number of Lines of Business Involved

\section{$\underline{\text { Number of Announcements }} \underline{\text { Percent of Total }}$}

Single-business alliance

Multiple-business alliance

Comprehensive-business alliance
80

20

9
$73.39 \%$

18.35

8.26 
Table 3: The Sample Distribution of 109 Strategic-Alliance Announcements by Different Characteristics

\section{$\underline{\text { Characteristic }}$}

Domestic firm/foreign firm

Equity tie-up

Investment product

Asset management

Intra-group

Insurance business

Investment banking

Inter-group

Others $\underline{\text { Number of Alliances }}$

60

52

37

24

17

7

7

5

20

Note: Each alliance may have multiple characteristics. 
Table 4: The (day -1, day 0) Abnormal Returns of 109 Alliance Announcements

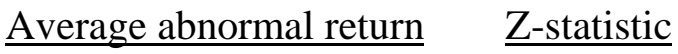

All sample (109 alliances)

$2.87 \%$

11.21

$\underline{\text { Median abnormal return }}$

All sample (109 alliances)

$1.39 \%$ 
Table 5: The Distribution of Domestic Alliances $(\mathrm{d} / \mathrm{f}=0)$, by the Numbers of Firms with Returns Data and the Signs of Their (day -1, day 0) Abnormal Returns Announcements

Total number of domestic alliances $(\mathrm{d} / \mathrm{f}=0): \mathbf{4 9}$

Number of domestic alliances with 2 or more publicly traded firms: 39

Number of domestic alliances with 2 publicly traded firms: 26

Signs of (day -1 , day 0 ) abnormal returns for the 2 firms:

$$
\begin{array}{lr}
+,+: & 13 \\
+,-: & 9 \\
-,-: & 4
\end{array}
$$

Number of domestic alliances with 3 publicly traded firms: 11

Signs of (day -1 , day 0 ) abnormal returns for the 3 firms:

$$
\begin{array}{ll}
+,+,+: & 3 \\
+,+,-: & 4 \\
+,-,-: & \mathbf{1} \\
-,-,-: & \mathbf{3}
\end{array}
$$

Number of domestic alliances with 4 publicly traded firms: 2

Signs of (day -1 , day 0 ) abnormal returns for the 4 firms:

$+,+,+,-: 1$

$-,-,-,-: \quad 1$ 
Table 6: Firm-Specific (day -1 , day 0) Abnormal Returns for Domestic Alliance $(\mathrm{d} / \mathrm{f}=0$ ) Announcements

Total number of domestic alliances ( $\mathrm{d} / \mathrm{f}=0)$ : $\mathbf{4 9}$

Number of domestic alliances with 2 or more publicly traded firms: 39

Number of domestic alliances with 2 publicly traded firms: $\mathbf{2 6}$

Number of announcements where the smaller firm showed the greater AR: 15

Mean difference in AR when the smaller firm showed the greater AR: $+5.23 \%$

Mean difference in AR when the larger firm showed the greater AR: $+\mathbf{2 . 6 2} \%$

Number of domestic alliances with 3 publicly traded firms: $\mathbf{1 1}$

Number of announcements where the smallest firm showed the greater AR: 6

Mean difference in AR when the smallest firm showed the greater AR: $\mathbf{+ 5 . 1 0 \%}$

Mean difference in AR when the largest firm showed the greater AR: $+3.37 \%$

Number of domestic alliances with 4 publicly traded firms: 2

Number of announcements where the smallest firm showed the greater AR: $\mathbf{1}$

Mean difference in AR when the smallest firm showed the greater AR: $\mathbf{+ 1 2 . 7 0 \%}$

Mean difference in AR when the largest firm showed the greater AR: $\mathbf{+ 0 . 5 5 \%}$

Overall (39 domestic alliances):

Number of announcements where the smaller firm showed the greater AR: 22

Mean difference in AR when the smallest firm showed the greater AR: $\mathbf{+ 5 . 5 3 \%}$

(s.e. $=1.51)$

Mean difference in AR when the largest firm showed the greater AR: $+\mathbf{2 . 7 2} \%$

$$
\text { (s.e. }=0.64)
$$


Table 7: The (day -1, day 0) Abnormal Returns for Foreign $(\mathrm{d} / \mathrm{f}=1)$ and Domestic $(\mathrm{d} / \mathrm{f}=0)$ Alliance Announcements

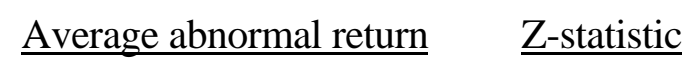
All sample (109 alliances)
$\mathrm{D} / \mathrm{f}=0$ sample (49 alliances)

$2.87 \%$

$2.65 \%$

$3.13 \%$
11.21

8.78

7.01

\section{$\underline{\text { Median abnormal return }}$}
All sample (109 alliances)
$1.39 \%$
$\mathrm{D} / \mathrm{f}=1$ sample (60 alliances)
$1.48 \%$
$\mathrm{D} / \mathrm{f}=0$ sample (49 alliances)
$1.39 \%$ 
Table 8: Regression Results when (day -1, day 0) Abnormal Returns for Alliances Are the Dependent Variable (t-statistics are in parentheses)

\begin{tabular}{|c|c|c|c|}
\hline$\underline{\text { Variable }}$ & $\underline{\text { Regres. (1) }}$ & Regres. (2) & Regres. (3) \\
\hline Constant & $\begin{array}{r}4.67 \\
(3.31)\end{array}$ & $\begin{array}{r}1.72 \\
(1.24)\end{array}$ & $\begin{array}{r}4.36 \\
(2.64)\end{array}$ \\
\hline $\mathrm{D} / \mathrm{f}$ & $\begin{array}{r}-0.67 \\
(0.48)\end{array}$ & $\begin{array}{r}0.19 \\
(0.14)\end{array}$ & $\begin{array}{r}0.34 \\
(0.23)\end{array}$ \\
\hline Intra-group & $\begin{array}{r}-2.82 \\
(2.01)\end{array}$ & $\begin{array}{r}-3.04 \\
(2.33)\end{array}$ & $\begin{array}{r}-1.93 \\
(1.31)\end{array}$ \\
\hline Inter-group & $\begin{array}{r}1.40 \\
(0.46\end{array}$ & $\begin{array}{r}0.86 \\
(0.26)\end{array}$ & $\begin{array}{r}1.37 \\
(0.42)\end{array}$ \\
\hline Capital tie-up & $\begin{array}{r}0.06 \\
(0.06)\end{array}$ & $\begin{array}{r}1.31 \\
(1.18)\end{array}$ & $\begin{array}{r}0.29 \\
(0.24)\end{array}$ \\
\hline Insurance & $\begin{array}{r}-2.93 \\
(1.43)\end{array}$ & - & $\begin{array}{r}-3.75 \\
(1.72)\end{array}$ \\
\hline Investment product & $\begin{array}{r}-2.01 \\
(1.56)\end{array}$ & - & $\begin{array}{r}-2.94 \\
(1.99)\end{array}$ \\
\hline Asset management & $\begin{array}{r}-1.01 \\
(0.76)\end{array}$ & - & $\begin{array}{r}-2.40 \\
(1.55)\end{array}$ \\
\hline Investment banking & $\begin{array}{r}4.46 \\
(1.98)\end{array}$ & - & $\begin{array}{r}2.59 \\
(1.05)\end{array}$ \\
\hline Others & $\begin{array}{r}-1.50 \\
(0.92)\end{array}$ & - & $\begin{array}{r}-2.50 \\
(1.39)\end{array}$ \\
\hline Multiple-business & - & $\begin{array}{r}2.62 \\
(1.90)\end{array}$ & $\begin{array}{r}3.00 \\
(1.84)\end{array}$ \\
\hline Comprehensive-business & - & $\begin{array}{r}2.80 \\
(1.16)\end{array}$ & $\begin{array}{r}-0.05 \\
(0.02)\end{array}$ \\
\hline $\mathrm{R}^{2}$ & 0.21 & 0.16 & 0.24 \\
\hline $\mathrm{n}$ & 109 & 109 & 109 \\
\hline
\end{tabular}

Note: Weighted least squares regressions are used, with the inverse of the standard errors of the ARs as weights; see Saxonhouse (1976). 
Table 9: The (day -1, day 0) Abnormal Returns of Announcements Involving Intra-group and Inter-group Alliances

Number of intra-group alliance announcements: 17

Mean AR of intra-group announcements: $+\mathbf{+ 0 . 5 8 \%}$

Number of inter-group alliance announcements: 5

Mean AR of inter-group announcements: $\mathbf{+ 4 . 5 5 \%}$ 